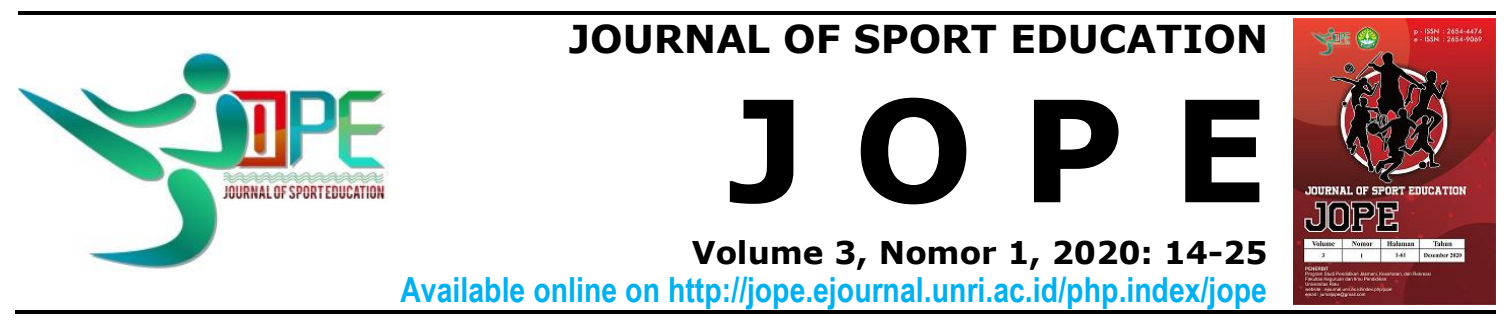

\title{
Pengembangan model pembelajaran passing bawah bola voli berbasis pendekatan saintifik
}

\author{
Cahyono Muarif Wibowo Pratama ${ }^{1}$ Hartati $^{2}$, Waluyo $^{3}$ \\ ${ }^{1,2,3}$ Universitas Sriwijaya \\ cahyopratama11@gmail.com¹, hartati@fkip.unsri.ac.id ${ }^{2}$,waluyounsri@yohoo.com³
}

Received: 23 Juli 2020; Revised: 06 September 2020; Accepted: 22 September 2020

http://dx.doi.org/10.31258/jope.3.1.14-25

\begin{abstract}
Abstrak
Penelitian ini bertujuan untuk mengembangkan model pembelajaran passing bawah bola voli berbasis pendekatan saintifik. Metode yang digunakan adalah research and development. Penelitian ini dilakukan uji coba skala kecil dan uji coba skala besar yang didalamnya terdapat tes unjuk kerja dan tes tertulis serta pemberian angket untuk mengetahui efektifitas model yang dikembangkan terhadap kemapuan kognitif, psikomotorik, dan afektif siswa. Subjek penelitian yang digunakan adalah 16 responden untuk uji coba skala kecil dan 48 responden untuk uji coba skala besar di SMK Negeri 1 Tanjung Batu. Hasil uji efektifitas model pada uji kelompok kecil diperoleh psikomotor 0,75 , hasil kognitif 0,73 berkategori tinggi yang didapatkan dengan analisis $n$-gain dan afektif dinilai dengan skala guttman $84,37 \%$ dan termasuk kategori tinggi. dan hasil uji coba skala besar hasil psikomotor 0,74 , hasil kognitif 0,76 berkategori tinggi yang didapatkan dengan analisis $n$-gain dan afektif dinilai dengan skala guttman 87,57\% dan termasuk kategori tinggi. Berdasarkan hasil penilaian ahli pembelajaran, uji coba skala kecil dan uji coba skala besar, maka model pembelajaran ini dinyatakan efektif meningkatkan kemampuan kognitif, psikomotorik, dan afektif siswa SMK.
\end{abstract}

Kata Kunci : pengembangan, model pembelajaran, passing bawah bola voli, pendekatan saintifik

\section{Development of volleyball under passing learning model based on the saintific approach}

\begin{abstract}
This study aims to develop a volleyball under-passing learning model based on a scientific approach. The method used is research and development. This research was conducted on small-scale trials and large-scale trials in which there were performance tests and written tests as well as questionnaires to determine the effectiveness of the developed model on students' cognitive, psychomotor, and affective abilities. The research subjects used were 16 respondents for small-scale trials and 48 respondents for large-scale trials at SMK Negeri 1 Tanjung Batu. The results of the model effectiveness test in the small group test obtained psychomotor 0.75, cognitive results were 0.73 in the high category obtained by $n$-gain analysis and affective was assessed with a Guttman scale of $84.37 \%$ and included in the high category. and the results of large-scale trials of psychomotor results of 0.74, cognitive results of 0.76 in the high category obtained by n-gain analysis and affective assessed by the Guttman scale of $87.57 \%$ and included in the high category. Based on the results of expert assessment of learning, small-scale trials and large-scale trials, this learning model is declared to be effective in improving the cognitive, psychomotor, and affective abilities of vocational high school students.
\end{abstract}

Keyword: development, learning model, passing under volleyball, scientific approach 
Journal of Sport Education (JOPE), 3 (1) 2020 - 15

Cahyono Muarif Wibowo Pratama ${ }^{1}$, Hartati $^{2}$, Waluyo $^{3}$

How To Cite: Pratama, C. M. W., Hartati., \& Waluyo. (2020). Pengembangan model pembelajaran passing bawah bola voli berbasis pendekatan saintifik. Journal of Sport Education (JOPE), 3 (1), 2020 : 14-25

\section{PENDAHULUAN}

Salah satu faktor yang akan menunjang keberhasilan proses belajar mengajar di kelas adalah ketepatan model pembelajaran yang digunakan oleh guru. Model pembelajaran adalah cara yang digunakan guru, yang dalam menjalankan fungsinya merupakan alat untuk mencapai tujuan pembelajaran (Aqib, 2013) Menurut Bloom dan Krathwohl dalam (Abdullah \& Dkk, 2004) menyatakan bahwa tujuan pendidikan dapat digolongkan menjadi tiga ranah atau domain yaitu ranah kognitif, ranah afektif dan ranah psikomotor. Jadi bisa kita kata idealnya dalam proses belajar mengajar model yang digunakan oleh guru hendaknya dapat membuat siswa mencapai tujuan pembelajaran pada ranah kognitif, psikomotorik, dan afektif.

Beberapa penelitian membuktikan bahwa model pembelajaran dapat menunjang keberhasilan proses belajar mengajar. (Subiantoro \& Hidayat, 2013) membuktikan bahwa penerapan model pembelajaran cooperative learning (Jigsaw) berpengaruh terhadap hasil belajar service bola voli pada siswa kelas VII A di SMPN 2 Tambelang Jombang.

Dalam kurikulum SMK Permainan bola voli merupakan permainan olahraga beregu yang termasuk dalam olahraga permainan bola besar. Hal ini bisa kita lihat pada kompetensi dasar yang harus dicapai yaitu 3.1 menganalisa keterampilan gerak salah satu permainan bola besar menghasilkan pembelajaran metode konvensional. Guru koordinasi gerak yang baik. (Anggraini et al., 2016) bahwa passing merupakan teknik dasar yang paling penting dalam permainan bola voli. Passing juga adalah operan bola kepada teman seregunya untuk dimainkan dalam lapangan sendiri. Dengan menguasai passing berarti permainan bisa berlangsung dengan baik, sebab passing merupakan salah satu teknik untuk menerima bola yang dilontarkan oleh lawan.

Pada saat peneliti melakukan observasi yang dilakukan peneliti di SMK Negeri 1 Tanjung Batu Kabupaten Ogan Ilir didapatkan permasalahan yaitu kemampuan siswa serta motivasi belajar siswa pada pendidikan jasmani olahraga dan kesehatan khusunya dalam pembelajaran di SMK Negeri 1 Tanjung Batu Kabupaten Ogan Ilir masih rendah. Peneliti melihat ketika siswa melakukan permainan bola voli kemampuan passing bawah siswa di SMK Negeri 1 Tanjung Batu masih rendah, sehingga permainan bola voli tidak berlangsung baik siswa hanya bergantian servis, jika bola lawan datang mereka tidak bisa mengembalikan bola ke daerah lawan. Selain itu dari wawancara yang dilakukan dengan siswa didapatkan tingkat kognitif siswa mengenai materi pembelajaran passing bawah juga masih rendah.

Hasil wawancara peneliti dengan guru pendidikan jasmani di sekolah tersebut didapatkan, memang sebagian besar guru masih terpaku pada paradigma lama yaitu pendidikan jasmani masih kurang kreatif 
Journal of Sport Education (JOPE), 3 (1) 2020 - 16

Cahyono Muarif Wibowo Pratama ${ }^{1}$, Hartati ${ }^{2}$, Waluyo ${ }^{3}$

dalam memberikan materi passing bawah, sehingga siswa tidak melakukan gerakan passing bawah tersebut dengan benar. Guru pendidikan jasmani di SMK Negeri 1 Tanjung Batu Kabupaten Ogan Ilir hanya mencontohkan siswa beberapa kali passing bawah kemudian meminta mereka berlatih sendiri. Pembelajaran konvesional adalah proses belajar mengajar secara tradisional dengan metode ceramah, metode tanya jawab dan metode penugasan. Metode konvensional yang pembelajaran yang berpusat pada guru, sehingga mengakibatkan siswa kurang aktif dan termotivasi dalam mengikuti pembelajaran (Djamarah, 2010). Situasi seperti ini kurang mendukung atas kemampuan siswa terutama dalam memahami materi pembelajaran. Hal ini menyebabkan banyak materi pembelajaran yang tidak tersampaikan kepada siswa sehingga pencapaian tujuan pembelajaran pada ranah kognitif, psikomotorik, dan afektif tidak tercapai dengan baik.

Dari permasalahan yang ditemukan maka peneliti akan mengembangkan model pembelajaran berbasis pendekatan saintifik sebagai solusi dari permasalahan passing bawah di SMK Negeri 1 Tanjung Batu Kabupaten Ogan Ilir. Hal ini dikarenakan salah satu pendekatan pembelajaran yang memberi ruang lebih banyak pada pemecahan masalah bagi siswa adalah pendekatan saintifik (Nuralam \& Eliyana, 2018). Pembelajaran bola voli di sekolah merupakan materi yang tercantum dalam pendekatan saintifik. Kurikulum dirancang secara kreatif, sehingga dapat dicapai tujuan pembelajaran yang ingin dicapai.

Menurut (Manik \& Sihotang, 2015) penerapan pendekatan saintifik melalui gaya mengajar pemecahan masalah merupakan metode pembelajaran yang bersifat membentuk suatu kelompok belajar untuk mempermudah suatu proses kegiatan belajar mengajar. Dimana suatu kelompok belajar itu adalah dengan cara : 1). Mengamati, 2) Menanya, 3) Mencoba, 4) mengasosiasi, 5) Mengomunikasikan. Dengan penerapan pendekatan saintifik melalui gaya mengajar pemecahan masalah, diharapkan siswa dapat memahami dan melakukan passing bawah bola voli dengan benar dan sesuai dengan penerapan pendekatan saintifik melalui gaya mengajar pemecahan masalah.

Berlandaskan pemikiran tersebut, sebagai upaya mengembangkan model pembelajaran passing bawah permainan bola voli sesuai pendekatan saintifik, maka peneliti akan mengadakan penelitian dengan judul "Pengembangan Model Pembelajaran Passing Bawah Permainan Bola Voli Berbasis Pendekatan Saintifik pada Siswa SMK Negeri 1 Tanjung Batu Kabupaten Ogan Ilir".

Tujuan penelitian ini adalah sebagai untuk mengetahui efektifitas model pembelajaran passing bawah permainan bola voli berbasis pendekatan saintifik yang dikembangkan terhadap meningkatkan kognitif, psikomotorik dan afektif siswa dalam passing bawah permainan bola voli di SMK Negeri 1 Tanjung Batu Kabupaten Ogan ilir. 
Journal of Sport Education (JOPE), 3 (1) 2020 - 17

Cahyono Muarif Wibowo Pratama ${ }^{1}$, Hartati ${ }^{2}$, Waluyo ${ }^{3}$

\section{METODE}

Penelitian ini menggunakan metode Research and Development. Metode penelitian dan pengembangan adalah metode penelitian yang digunakan untuk menghasilkan produk tertentu, dan menguji keefektifan produk tersebut. Model pengembangan adalah model yang bersifat deskriptif, menunjukkan langkah-langkah yang harus diikuti untuk menghasilkan produk. Pada penelitian ini menggunakan model pengembangan menurut (Sugiyono, 2014) langkah-langkah dalam penelitian R\&D yaitu (1) Analisis Kebutuhan , (2) Model awal, (3) Validasi model awal, (4) Deskripsi Validasi Ahli (5) Revisi desain awal, (6) Uji coba produk, (7) Revisi produk (8) Uji coba pemakaian, (9) Revisi produk, (10) Produk akhir.

Subjek dalam penelitian pengembangan ini terbagi menjadi dua kelompok. Uji coba kelompok skala kecil dilakukan pada 16 siswa SMK Negeri 1 Tanjung Batu. Uji coba kelompok skala besar dilakukan pada 48 siswa SMK Negeri 1 Tanjung Batu.

Instrument penelitian berupa tes lima soal uraian untuk ranah kognitif, 10 soal angket untuk ranah afektif, serta tes unjuk kerja untuk menguji psikomotorik siswa.

Hasil data yang didapatkan akan divalidasi menggunakan n-gain untuk analisa tes psikomotorik dan tes kognitif, serta analisis skala guttman untuk ranah afektif.

\section{HASIL DAN PEMBAHASAN}

Hasil temuan yang didapatkan dilapangan lalu dideskripsikan sehingga diperoleh suatu rumusan hasil data yang telah dikumpulkan, berikut ini akan dijabarkan mengenai hasil analisis kebutuhan yang diperoleh oleh peneliti yaitu didapatkan kemampuan siswa pada terutama pada aspek kognitif, psikomotor dan afektif passing bawah masih minim atau kurang sehingga kemampuan yang didapat siswa untuk pembelajaran keterampilan passing bawah permainan bola voli masih jauh dari yang diharapkan.

Kemudian peneliti melakukan studi pendahuluan dengan menggunakan wawancara yang mendalam (in-depth interview) kepada guru dan siswa yang berada di SMK Negeri 1 Tanjung Batu serta melakukan survey untuk mencari solusi dari permasalahan passing bawah yang ditemukan.

Peneliti juga telah melakukan observasi terhadap sarana dan prasarana dalam menunjang pembelajaran keterampilan passing bawah permainan bola voli, dalam observasi ditemukan bola dan net yang ada dalam keadaan baik serta layak untuk digunakan, lapangan terbuka juga ada dan dalam keadaan baik serta rata permukaannya, sehingga dari hasil observasi tersebut peneliti membuat suatu proses pembelajaran yang menarik untuk siswa agar lebih mudah untuk memahami mengenai materi keterampilan passing bawah permainan bola voli.

Pada penelitian ini peneliti akan mengembangkan produk model pembelajaran dengan pendekatan saintifik. Adapun kegiatan pembelajaran pada model tersebut adalah

1) siswa mengamati video pembelajaran. 
Journal of Sport Education (JOPE), 3 (1) 2020 - 18

Cahyono Muarif Wibowo Pratama ${ }^{1}$, Hartati ${ }^{2}$, Waluyo ${ }^{3}$

2) siswa mencoba melakukan passing bawah.

3) siswa melakukan tanya jawab dengan guru mengenai passing bawah.

Validasi dilakukan dengan cara memberikan draf produk awal pengembangan model pembelajaran passing bawah permainan bola voli berbasis pendekatan saintifik pada siswa Sekolah Menengah Kejuruan, dengan disertai lembar evaluasi dan revisi satu orang ahli pembelajaran seorang guru pendidikan jasmani olahraga dan kesehatan SMK Negeri
1 Tanjung Batu yaitu bapak Retno Jamaluddin, S.Pd dan Dosen Universitas Sriwijaya yaitu Ibu Destriani, M.Pd sebagai ahli materi.

Berdasarkan hasil pengisian kuisioner terhadap draft model yang dikembangkan yang dilakukan oleh guru penjaskes didapatkan rata-rata sebesar 3,8 tenaga ahli psikomotorik didapatkan rata-rata sebesar 3,9 dan masuk dalam kategori penilaian "PRAKTIS dan VALID.

Tabel 1. Rerata dan Kategori Nilai Angket Validasi Ahli

\begin{tabular}{ccc}
\hline Rerata & Kategori & Kategori \\
\hline $4,21-5,00$ & Sangat Praktis & Sangat Valid \\
\hline $3,41-4,20$ & Praktis & Valid \\
\hline $2,61-3,40$ & Cukup Praktis & Cukup Valid \\
\hline $1,81-2,60$ & Tidak Praktis & Tidak Valid \\
\hline $1,00-1,80$ & Sangat tidak praktis & Sangat Tidak Valid \\
\hline
\end{tabular}

Sumber: (Sugiyono, 2017)

Oleh karena itu dapat disimpulkan bahwa saintifik pada siswa SMK Negeri 1 Tanjung draf model pembelajaran passing bawah Batu layak untuk digunakan dalam permainan bola voli berbasis pendekatan pembelajaran passing bawah bola voli.

Tabel 2. Revisi Produk Awal

\begin{tabular}{clll}
\hline No & Bagian yang Direvisi & \multicolumn{1}{c}{ Saran Perbaikan } & \multicolumn{1}{c}{ Keterangan } \\
\hline 1 & $\begin{array}{l}\text { Kesesuaian dengan } \\
\text { kompetensi dasar dalam } \\
\text { pembelajaran PJOK bagi } \\
\text { siswa }\end{array}$ & $\begin{array}{l}\text { Disesuaikan dengan } \\
\text { waktu pembelajaran } \\
\text { siswa yang digunakan }\end{array}$ & $\begin{array}{l}\text { Waktu pembelajaran yang } \\
\text { terbatas perlu disikapi seorang } \\
\text { guru }\end{array}$ \\
\hline 2 & $\begin{array}{l}\text { Kejelasan petunjuk } \\
\text { permainan }\end{array}$ & $\begin{array}{l}\text { Petunjuk permainan } \\
\text { harus lebih terperinci }\end{array}$ & $\begin{array}{l}\text { Petunjuk permainan yang } \\
\text { terperinci dan jelas memudahkan } \\
\text { siswa untuk mempraktekannya }\end{array}$ \\
\hline 3 & $\begin{array}{l}\text { Ketepatan memilih } \\
\text { bentuk atau model } \\
\text { pembelajaran permainan } \\
\text { passing bawah bola voli } \\
\text { bagi siswa }\end{array}$ & $\begin{array}{l}\text { Ditulis Model } \\
\text { pembelajaran apa yang } \\
\text { digunakan }\end{array}$ & $\begin{array}{l}\text { Kesesuaian model yang } \\
\text { digunakan sangat mempengaruh } \\
\text { keberhasilan pembelajaran }\end{array}$ \\
\hline 4 & $\begin{array}{l}\text { Kesesuaian model } \\
\text { pembelajaran passing } \\
\text { bawah bola voli bagi } \\
\text { siswa }\end{array}$ & $\begin{array}{l}\text { Ditambah sesuai } \\
\text { dengan karakteristik } \\
\text { siswa }\end{array}$ & $\begin{array}{l}\text { Karena pendidikan yang } \\
\text { disampaikan oleh guru, tanpa } \\
\text { mempunyai teori di praktek tidak } \\
\text { berhasil }\end{array}$ \\
\hline
\end{tabular}

Sumber: Data diolah, 2020

Produk yang telah direvisi dilanjutkan yang terbagi menjadi kelompok kecil dan dengan melakukan pengujian pada siswa kelompok besar. 
Journal of Sport Education (JOPE), 3 (1) 2020 - 19

Cahyono Muarif Wibowo Pratama ${ }^{1}$, Hartati $^{2}$, Waluyo $^{3}$

Uji coba lapangan kelompok kecil yang dilaksanakan menggunakan sampel penelitian berjumlah 16 siswa SMK Negeri 1 dihimpun dengan menggunakan evaluasi penilaian meliputi ranah (kognitif, psikomotor dan afektif).

Tanjung Batu. Data uji coba lapangan

Tabel 3. Data Rekapitulasi Presentase Keberhasilan Uji Coba Kelompok Kecil

\begin{tabular}{cccc}
\hline Ranah pengetahuan & Metode analisa & Hasil analisa & kategori \\
\hline Psikomotorik & $n$-gain & 0,75 & Tinggi \\
\hline kognitif & $n$-gain & 0,73 & Tinggi \\
\hline afektif & Skala guttman & $84,37 \%$ & Tinggi \\
\hline
\end{tabular}

Sumber: Data diolah, 2020

Berdasarkan analisis evaluasi penilaian pada tabel 3 maka didapat hasil dari ranah kognitif, psikomotor, afektif, siswa SMK pada uji coba kelompok kecil diperoleh psikomotor 0,75, hasil kognitif o,73 berkategori tinggi yang didapatkan dengan analisis $n$-gain dan afektif dinilai dengan skala guttman $84,37 \%$ dan termasuk kategori tinggi. Berdasarkan kriteria yang telah ditentukan maka, model pembelajaran bola voli berbasis pendekatan saintifik pada siswa
SMK memiliki pengaruh tinggi terhadap kemampuan psikomotorik, kognitif, dan afektif siswa SMK.

Uji coba lapangan yang dilaksanakan pada kelompok besar dengan menggunakan sampel penelitian berjumlah 48 siswa SMK Negeri 1 Tanjung Batu. Data uji coba lapangan dihimpun dengan menggunakan evaluasi penilaian meliputi ranah (kognitif, psikomotor dan afektif)

Tabel 4. Data Rekapitulasi Presentase Keberhasilan Uji Coba Kelompok Besar

\begin{tabular}{cccc}
\hline Ranah pengetahuan & Metode analisa & Hasil analisa & kategori \\
\hline Psikomotorik & $n$-gain & 0,74 & Tinggi \\
\hline kognitif & n-gain & 0,76 & Tinggi \\
\hline afektif & Skala guutman & 87,5 & Tinggi \\
\hline
\end{tabular}

Sumber: Data diolah, 2020

Berdasarkan data yang diperoleh dari

afektif.

kuisioner uji coba kelompok besar pada tabel

Proses pembelajaran pada dasarnya 3 maka diperoleh hasil psikomotor 0,74 , hasil kognitif 0,76 berkategori tinggi yang didapatkan dengan analisis n-gain dan afektif dinilai dengan skala guttman $87,57 \%$ dan termasuk kategori tinggi. Berdasarkan kriteria yang telah ditentukan maka, model pembelajaran bola voli berbasis pendekatan saintifik pada siswa SMK ini telah berpengaruh tinggi terhadap pencapaian siswa dibidang kognitif, psikomotorik, dan merupakan interaksi pedagogis antara guru, siswa, materi, dan lingkungannya (Gustiawati, 2017). Menurut (Sinulingga \& Nugraha, 2017) proses pembelajaran yang mengimplementasikan pendekatan saintifik akan menyentuh tiga ranah, yaitu: sikap (afektif), pengetahuan (kognitif), dan keterampilan (psikomotor). Hasil evaluasi pembelajaran yang meliputi aspek kognitif, psikomotor, dan afektif pada penelitian ini 
Journal of Sport Education (JOPE), 3 (1) 2020 - 20

Cahyono Muarif Wibowo Pratama ${ }^{1}$, Hartati $^{2}$, Waluyo $^{3}$

dijabarkan sebagai berikut :

Menurut (Susanto, 2014) kognitif adalah suatu proses berpikir, yaitu kemampuan individu untuk menghubungkan, menilai, dan mempertimbangkan suatu kejadian atau peristiwa. Pada penelitian ini kemampuan kognitif siswa diukur dari hasil tes tertulis dengan menjawab lima pertanyaan mengenai passing bawah. Pada uji kelompok kecil hasil kognitif diuji dengan $N$-gain didapatkan hasil 0,73 berkategori tinggi hanya dua siswa yang nilainya berada dikategori cukup dengan kata lain 87,5\% siswa sudah mencapai nilai KKM yang ditentukan dan pada uji kelompok besar didapatkan hasil kognitif 0,76 berkategori tinggi dari 48 siswa yang dijadikan subjek penelitian 83,33\% siswa sudah mencapai nilai KKM 75 yang ditetapkan.

Penggunaaan pendekatan saintifik ini merujuk pada hasil penelitian yang dilakukan oleh (Azizah, 2018) yang berjudul Penerapan Model Think Talk Write Berbasis Saintifik Untuk Meningkatkan Hasil Belajar Tema Kebersamaan dari hasil analisis data yang diperoleh menunjukkan hasil adanya peningkatan hasil belajar siswa karena aktivitas selama pembelajaran. Persentase hasil belajar siklus I muatan Bahasa Indonesia sebesar 78,95\% dan pada siklus II sebesar 100\%. Sedangkan persentase ketuntasan pada Matematika dalam siklus I sebesar $81,6 \%$ dan siklus II sebesar $92 \%$. Berdasarkan hasil tersebut, penelitian dengan model ttw berbasis saintifik dapat meningkatkan hasil belajar siswa.

Penelitian relevan yang dilakukan oleh
(Fatmawati et al., 2018) yang berjudul Perbedaan Hasil Belajar Siswa melalui Pendekatan Konvensional dengan Pendekatan Saintifik pada Kompetensi Dasar Fungsi Manajemen Siswa. Hasil penelitian menunjukan bahwa terdapat perbedaan yang signifikan hasil belajar siswa yang diajar menggunakan pendekatan saintifik dengan pendekatan konvensional pada kompetensi dasar fungsi manajemen siswa kelas $\mathrm{X}$ di SMA Negeri 4 Jember Tahun Ajaran 2016/2017.

Penelitian relevan yang dilakukan oleh (Ernailis, 2016) yang berjudul Peningkatan Keterampilan Passing Bawah Bola Voli melalui Strategi Pembelajaran Sesama Teman. Hasil penelitian menunjukan bahwa keterampilan gerak dasar passing bawah siswa siswa kelas IV SD Negeri 001 Empat Balai, Kecamatan Kuok, Kabupaten Kampar dapat ditingkatkan melalui strategi pembelajaran sesama teman. Hal ini menunjukkan bahwa ketuntasan kasikal telah tercapai, di mana penelitian dikatakan berhasil bila ketuntasan yang dicapai $80 \%$ siswa memperoleh nilai minimal 70.

Dalam Kamus Besar Bahasa Indonesia (KBBI), psikomotorik diartikan sebagai suatu aktivitas fisik yang berhubungan dengan proses mental dan psikologi. Psikomotorik berkaitan dengan tindakan dan keterampilan, seperti lari, melompat, melukis, dan sebagainya (Haryadi \& Arifin, 2015).

Pada penilaian psikomotorik dilakukan tes unjuk kerja passing bawah sebelum dan sesudah pembelajaran. Tes unjuk kerja ini 
Journal of Sport Education (JOPE), 3 (1) 2020 - 21

Cahyono Muarif Wibowo Pratama ${ }^{1}$, Hartati ${ }^{2}$, Waluyo ${ }^{3}$

melihat sikap kaki, sikap tangan, sikap badan, dan perkenaan bola saat siswa melakukan passing bawah. Dari kegiatan uji kelompok kecil didapatkan jika sebelum menggunakan model pembelajaran hanya 25 \% siswa yang mencapai KKM maka setelah melakukan pembelajaran menggunakan model pembelajaran 14 orang dari 16 orang siwa sudah mencapai KKM dengan presentase 93,75\%. Hasil dari uji n-gain didapatkan bahwa peningkatan berada di nilai 0,75 dengan kategori tinggi.

Pada uji kelompok besar didapatkan pada pretest 37 siswa dari 48 subjek penelitian mendapatkan nilai dibawah 75 sehingga tingkat keberhasilan pembelajaran hanya $22,01 \%$. Setelah melakukan pembeajaran posttest yang didapatkan terdapat peningkatan hasil psikomotrik siswa yaitu 46 siswa sudah berhasil mencapai nilai 75 sehingga tingkat keberhasilan pembelajaran menjadi $95,83 \%$. Nilai pretest dan posttest ini kemudian diuji dengan $n$-gain untuk melihat peningkatannya dan didapatkan $n$-gain pada psikomotorik siswa dengan rata-rata 0,74 dan berada di kategori tinggi.

Kibler, Barket dan Miles (Irma, 2019) mengemukakan taksonomi aspek psikomotorik meliputi gerakan tubuh yang mencolok, ketepatan gerakan yang dikoordinasikan. Sedangkan menurut Sudjana dalam (Tri Indra Prasetya, 2012) hasil belajar psikomotorik tampak dalam bentuk keterampilan dan kemampuan bertindak individu. Dari hasil uji kelompok kecil dan uji kelompok besr didapatkan adanya peningkatan kemampuan psikomotorik siswa SMK kelas XI dalam passing bawah setelah melakukan pembelajaran dengan menggunakan model pembelajaran berbasis saintifik yang dikembangkan. (Iyakrus, 2018) menyatakan pendidikan jasmani akan membantu mewujudkan tujuan-tujuan yang menyangkut perekembangan social, kerjasama, kesan tentang pribadi yang menyenangkan, pengambilan keputusan, kreatif, keterampilan motoric, kesegaran jasmani, pemahaman tentang gerakan manusia yang lebih utama menuju prestasi olahraga.

Keberhasilan model pembelajaran passing bawah bola voli berbasis pendekatan saintifik ini menjadikan pendekatan saintifik sebagai solusi dari permasalahan dalam proses pembelajaran penjaskes. Beberapa penelitian sebelumnya juga didapatkan jika pendekatan saintifik dapat meningkatkat hasil belajar siswa. Penelitian yang dilakukan oleh (Marwoto et al., 2016) dengan judul Peningkatan Hasil Belajar Lari Estafet Melalui Pendekatan Saintifik Pada Siswa Kelas VI SD Negeri Salaman 4 Tahun 2016 didapatkan hasil pembelajaran lari estafet melalui pendekatan saintifik pada siswa kelas VI SDN Salaman 4 Kecamatan Salaman Kabupaten Magelang menunjukkan peningkatan yang sangat signifikan.

Menurut Sudjana dalam (Tri Indra Prasetya, 2012) aspek afektif berhubungan dengan sikap dan nilai. Tipe hasil belajar afektif tampak dalam berbagai tingkah laku seperti perhatiannya terhadap pelajaran, disiplin, motivasi belajar, menghargai guru dan teman sekelas, kebiasaan belajar, dan hubungan 
Journal of Sport Education (JOPE), 3 (1) 2020 - 22

Cahyono Muarif Wibowo Pratama ${ }^{1}$, Hartati ${ }^{2}$, Waluyo ${ }^{3}$

social.

Aspek afektif pada penelitian ini dinilai dari hasil angket motivasi siswa yang berisikan 10 pertanyaan menggunakan sekala Guttman dengan jawaban ïya'atau 'tidak'dari hasil kelompok kecil didapatkan tingkat motivasi siswa yaitu $84,37 \%$ dan termasuk kategori tinggi dengan pada uji kelompok besar didapatkan $87,57 \%$ dan termasuk kategori tinggi.

Selama ini guru penjaskes melakukan pembelajaran konvesional yakni proses belajar mengajar secara tradisional dengan metode ceramah, metode tanya jawab dan metode penugasan. Metode konvensional yang pembelajaran yang berpusat pada guru, sehingga mengakibatkan siswa kurang aktif dan termotivasi dalam mengikuti pembelajaran (Djamarah, 2010)

Pada pembelajaraan ini guru memanfaatkan media pembelajaran untuk meningkatkan motivasi belajar siswa. Menurut Sudjana dan Rivai (Susanto, 2016) mengemukakan manfaat media pengajaran dalam proses belajar siswa yaitu; (a) pengajaran akan lebih menarik siswa sehingga dapat menumbuhkan motivasi belajar; (b) bahan pengajaran akan lebih jelas sehingga dapat lebih dipahami oleh siswa dan memungkinkannya menguasai dan mencapai tujuan pengajaran; (c) metode mengajar akan lebih bervariasi, tidak semata-mata komunikasi verbal melalui penuturan kata-kata oleh guru sehingga siswa tidak bosan dan guru tidak kehabisan tenaga, apalagi kalau guru mengajar pada setiap jam pelajaran; (d) siswa dapat lebih banyak melakukan kegiatan belajar sebab tidak hanya mendengarkan uraian guru, tetapi juga aktivitas lain seperti mengamati, melakukan, mendemonstrasikan, memamerkan dan lainlain.

Kegiatan yang berlangsung menciptakan pembelajaran yang lebih menarik dan tidak biasa. Hal ini diperkuat oleh pendapat dari Kusniarti, T., Si, M., Mujianto, G., \& Sudjalil, yang dikutip oleh (Azizah, 2018) yang mengemukakan bahwa aktivitas pembelajaran di kelas menjadi lebih hidup jika selalu melibatkan siswa karena dikenalkannya pembelajaran dengan pendekatan saintifik.

Hasil penelitian ini juga memperkuat pendapat (Wibowo, 2016) mengenai pentingnya Keaktifan siswa yakni keaktifan peserta didik dalam proses pembelajaran dapat merangsang dan mengembangkan bakat yang dimilikinya, peserta didik juga dapat berlatih untuk berfikir kritis, dan dapat memecahkan permasalahan permasalahan. Keaktifan siswa dalam proses pembelajaran yang rendah jika dibiarkan akan berdampak yang kurang baik, dan akhirnya berdampak pada hasil belajar kurang memuaskan. Dengan kata lain keberhasilan model pembelajaran ini meningkatkan keaktifan siswa pada kegiatan belajar juga mempengaruhi hasil kemampuan kognitif dan psikomotorik siswa yang pada uji coba kelompok kecil ini mengalami peningkatan dengan kategori tinggi.

\section{KESIMPULAN}

Hasil penelitian pengembangan model pembelajaran passing bawah permainan bola 
Journal of Sport Education (JOPE), 3 (1) 2020 - 23

Cahyono Muarif Wibowo Pratama ${ }^{1}$, Hartati $^{2}$, Waluyo $^{3}$

voli berbasis pendekatan saintifik pada siswa SMK Negeri 1 Tanjung Batu Kabupaten Ogan Ilir dapat disimpulkan efektif meningkatkan kognitif, psikomotorik dan afektif siswa dalam passing bawah permainan bola voli siswa SMK Negeri 1 Tanjung Batu Kabupaten Ogan Ilir.

\section{DAFTAR PUSTAKA}

Abdullah, \& Dkk. (2004). Panduan Kurikulum Prasekolah. Malindo.

Anggraini, A. W., Tomi, A., \& Sulistyorini. (2016). Meningkatkan Keterampilan Passing Bawah Menggunakan Latihan Bervariasi Pada Siswa Peserta Ekstrakurikuler Bola Voli Smk Negeri 2 Singosari Kabupaten Malang. Jurnal Pendidikan Jasmani, 26(02), 365-380.

Aqib, Z. (2013). Model-model, Media, dan

Strategi Pembelajaran Kontekstual (Inovatif). Yrama Widya.

Azizah, S. N. (2018). Penerapan Model Think Talk Write Berbasis Tema Kebersamaan. 4(November), 160-171.

Djamarah, S. (2010). Strategi Belajar Mengajar. Rineka Cipta.

Ernailis. (2016). Peningkatan Keterampilan Passing Bawah Bola Voli Melalui Strategi Pembelajaran Sesama Teman Pada Siswa Kelas IV SD Negeri 001 Empat Balai Kecamatan Kuok Kabupaten Kampar. Journal Primary, 5(September), 52-61.
Fatmawati, L., Sukidin, S., \& Suyadi, B. (2018). Perbedaan Hasil Belajar Siswa Melalui Pendekatan Konvensional Dengan Pendekatan Saintifik Pada Kompetensi Dasar Fungsi Manajemen Siswa Kelas X Di Sma Negeri 4 Jember Tahun Ajaran 2016/2017. JURNAL PENDIDIKAN EKONOMI: Jurnal Ilmiah Ilmu Pendidikan, Ilmu Ekonomi Dan Ilmu Sosial, 11(2), 134. https://doi.org/10.19184/jpe.v11i2.6460

Gustiawati, R. (2017). Implementasi ModelModel Pembelajaran Penjas dalam Meningkatkan Kemampuan Guru Memilih dan Mengembangkan Strategi Pembelajaran Pendidikan Jasmani Olahraga dan Kesehatan. JOSSAE: Journal of Sport Science and Education, $\quad 1(1), \quad 27$. https://doi.org/10.26740/jossae.v1n1.p2 7-31

Haryadi, T., \& Arifin. (2015). Melatih Kecerdasan Kognitif, Afektif, dan Psikomotorik Anak Sekolah Dasar Melalui Perancangan Game Simulasi "WARUNGKU." , Jurnal Desain Komunikasi Visual \& Multimedia, 01, $39-50$.

Irma, A. (2019). Penggunaan Metode Demonstrasi Dalam Meningkatkan Proses Belajar dan Hasil Belajar Bahasa Indonesia Pada Siswa SMP Negeri 1 Wera Tahun Pelajaran 2016/2017. Jurnal Pendidikan Mandala, 53(9), 1689-1699. 
Journal of Sport Education (JOPE), 3 (1) 2020 - 24

Cahyono Muarif Wibowo Pratama ${ }^{1}$, Hartati ${ }^{2}$, Waluyo ${ }^{3}$

https://doi.org/10.1017/CBO978110741

5324.004

Iyakrus. (2018). Pendidikan Jasmani , Olahraga, dan Prestasi. Jurnal Ilmu Olahraga Dan Kesehatan, 7. https://doi.org/10.36706/altius.v7i2.811 0

Manik, A. C., \& Sihotang, J. M. (2015). Penerapan Saintifik Melalui Gaya Mengajar Pemecahan Masalah Pada Passing Bawah Bola Voli. Jurnal Pedagogik Olahraga, 1(2), 57-68. https://jurnal.unimed.ac.id/2012/index.p hp/jpor/index

Marwoto, W. G., Pujiyanto, A., \& Pamot, H. (2016). Hasil Belajar Lari Estafet Melalui Pendekatan Saintifik Pada Siswa Kelas VI SD Negeri Salaman 4. Journal of Physical Education, Health and Sport, 3(2), 121-126.

Nuralam, N., \& Eliyana, E. (2018). Penerapan Pendekatan Saintifik Terhadap Kemampuan Pemecahan Masalah Matematika Di Sman 1 Darul Imarah Aceh Besar. Jurnal Ilmiah Didaktika, $\quad 18(1), \quad 64$. https://doi.org/10.22373/jid.v18i1.3085

Sinulingga, A., \& Nugraha, T. (2017). Penerapan Pendekatan Ilmiah Pada Pelajaran Pendidikan Jasmani Olahraga dan Kesehatan dan Dampaknya Pada Siswa SMA Negeri 15 Medan. Jurnal Pedagogik Olahraga, 03(JuliDesember), 72-98.
Subiantoro, F., \& Hidayat, T. (2013). Penerapan Model Pembelajaran Cooperative Learning (Jigsaw) Terhadap Hasil Belajar Service Bola Voli (Studi Pada Siswa Kelas VII SMPN 2 Tembelang Jombang). Jurnal Pendidikan Olahraga Dan Kesehatan, 1(2), 265-273.

Sugiyono. (2014). Metode Penelitian Pendidikan (Pendekatan Kuantitatif Kualitatif dan $R \& D$ ). Alfabeta.

Sugiyono. (2017). Metode Penelitian dan Pengembangan Research and Development. Alfabeta.

Susanto, A. (2014). Teori Belajar dan Pembelajaran di Sekolah Dasar. Kencana Prenada Media Group.

Susanto, A. (2016). Teori Belajar \&Pembelajaran di Sekolah Dasar. Prenadamedia Group.

Tri Indra Prasetya. (2012). Keterampilan, Meningkatkan Instrumen, Menyusun Berbasis, Belajar Interaktif, Modul IPA SMP Bagi Guru-Guru Kota Magelang. Journal of Educational Research and Evaluation, 1(2).

Wibowo, N. (2016). Upaya Peningkatan Keaktifan Siswa Melalui Pembelajaran Berdasarkan Gaya Belajar Di Smk Negeri 1 Saptosari. Elinvo (Electronics, Informatics, and Vocational Education), $\quad$ 1(2), 128-139. https://doi.org/10.21831/elinvo.v1i2.10 
Journal of Sport Education (JOPE), 3 (1) 2020 - 25

Cahyono Muarif Wibowo Pratama ${ }^{1}$, Hartati ${ }^{2}$, Waluyo ${ }^{3}$

621 